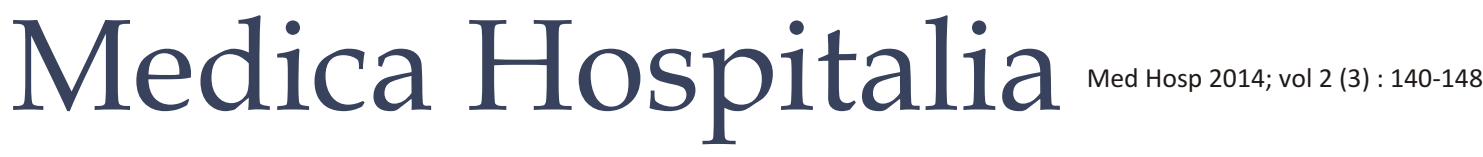

Review Article

Medical Progress

\section{Terapi Nutrisi pada Pasien ICU}

\author{
Ibnu, Dhany Budipratama, Tinni T. Maskoen \\ Departemen Anestesiologi dan Terapi Intensif \\ Fakultas Kedokteran Universitas Padjadjaran RSUP Dr. Hasan Sadikin Bandung
}

\begin{abstract}
Abstrak
Malnutrisi sering dikaitkan dengan peningkatan tingkat morbiditas dan mortalitas akibat perburukan sistem kekebalan tubuh, ketergantungan pada ventilator, tingginya angka infeksi, dan lamanya proses kesembuhan, sehingga menyebabkan lama perawatan memanjang dan meningkatkan biaya perawatan pasien. Klinisi harus mengetahui informasi yang benar tentang bagaimana cara mengatur nutrisi pada penderita sakit kritis karena dapat mempengaruhi outcome pasien ICU. Tujuan terapi nutrisi pada penderita sakit kritis adalah untuk menunjang proses metabolisme, bukan untuk memenuhi kebutuhannya saat itu. Karena penderita sakit berat tidak pada kondisi metabolik yang dapat untuk memetabolisme jumlah kalori total untuk memenuhi kebutuhan pengeluaran energi.
\end{abstract}

Kata kunci : Terapi nutrisi, Pasien ICU

\section{Nutritional therapy in ICU patient}

\section{Abstract}

Malnutrition is always been being associated with the increase of morbidity and mortality rate due to lack of immune system, depending on ventilator, high rate of infection, and delayed healing process, so it will increase the cost and length of stay patient. Clinician need to have right information about how to manage nutrition for critical care ill pateint because it will influece the outcome of ICU patient. The goal in nutrition therapy in critical ill patient is to dukungan metabolisme, not to complete their need in that time. Because in critical ill patient there is no metabolic condition is able to metabolize total amount of calories to fulfill lack of energy expenses.

Keywords : Nutrition therapy, ICU patient

\section{PENDAHULUAN}

Tujuan dasar dari nutrisi adalah menyediakan kebutuhan sehari - hari setiap pasien. Sesuai dengan hukum termodinamik, energi dapat dihasilkan dan dihancurkan, oleh karena itu, satu satunya cara untuk menghasilkan energi adalah dengan memindahkan sumber energi yang ada di alam. Substansi alami yang memiliki sumber energi disebut dengan bahan bakar, sedangkan alat yang dapat melakukan proses pemindahan energi disebut dengan mesin. ${ }^{1}$

Terapi nutrisi pada pasien sakit kritis sudah mengalami perubahan drastis selama 10 tahun terakhir meliputi penilaian status nutrisi, panduan kebutuhan energi, dan nutrisi pada penyakit - penyakit tertentu. Pemikikiran rasional untuk terapi nutrisi berdasarkan pengetahuan dimana pada pasien sakit kritis cenderung mengalami malnutrisi, dan hal tersebut berhubungan erat dengan komplikasi serius seperti sepsis atau pneumonia.
Pasien-pasien yang dirawat di ICU banyak yang mengalami kondisi malnutrisi. Kondisi ini dialami pasien pada saat datang ke ICU, atau merupakan hasil dari respons metabolik terhadap kondisi sakitnya itu. Respons terhadap cedera juga dapat memicu terjadinya perubahan komposisi tubuh dan defisiensi nutrisi yang tampakjelas secara klinis.

Pada kondisi kelaparan, tubuh menggunakan lemak dan protein sebagai sumber energi. Penggunaan lemak untuk bahan bakar sangat penting sebagai respons adaptasi untuk bertahan hidup, karena pada saat kelaparan glikogen sebagai cadangan glukosa hanya dapat menyediakan $1200 \mathrm{kkal}$ pada 24 jam pertama. Tubuh akan lebih banyak menggunakan protein otot daripada protein viseral, karena protein viseral sangat dibutuhkan untuk fungsi vital dari organ tubuh. ${ }^{2}$

\section{Penilaian Status Nutrisi}

Belum diketahui berapa lama pasien dengan sakit kritis mampu mentoleransi kekurangan nutrisi tanpa 
komplikasi. Penipisan jaringan mulai terjadi hari ke 14 pada kondisi kelaparan, hal ini yang menjadi dasar rekomendasi dimana dukungan nutrisi dapat dimulai pada pasien yang tidak bisa makan untuk waktu 7-10 hari.

Kebutuhan dukungan nutrisi ditentukan berdasarkan keseimbangan antara cadangan energi endogen tubuh dengan besarnya stres. penanda klinis terbaik dari stres adalah demam lekositosis, hipoalbumin, dan keseimbangan nitrogen yang negatif.

Tujuan dari penilaian status nutrisi adalah untuk mengidentifikasi tipe dan derajat malnutrisi, sehingga dapat dilakukan tindakan yang rasional. Persentasi kehilangan berat badan 6 bulan terakhir, level serum albumin, dan nilai total limfosit juga sering digunakan untuk menilai status nutrisi.

Penurunan berat badan sebanyak $10 \%$ atau $10 \mathrm{lbs}$ selama 12 bulan merupakan indikator dari malnutrisi kalori protein, akibat dari asupan kalori yang tidak adekuat. Malnutrisi hipoalbuminemia atau kwashiorkor terjadi akibat stres berat atau malnutrisi berat. Albumin bukan merupakan indikator yang sensitif dari malnutrisi pada pasien di ICU karena sintesa albumin dipengaruhi oleh berbagai macam faktor selain status nutrisi seperti kehilangan protein dalam waktu yang lama, gangguan fungsi hati, dan infeksi atau inflamasi akut.

Pada pasien sakit kritis nilai normal konsentrasi albumin akan sulit tercukupi karena perpindahan cairan dalam jumlah besar dan sintesis yang tidak adekuat untuk memenuhi kebutuhan. Malnutrisi kalori protein dapat ditangani dengan memberikan asupan kalori yang adekuat. Malnutrisi hipoalbumin efektif dengan terapi nutrisi dan penanganan faktor stres yang menyebabkan kondisi kataboliknya itu.

Kehilangan berat badan $10 \mathrm{lbs}$ atau 10\% dari berat badan merupakan tanda klinis yang penting. Kehilangan berat badan 20-30\% menandakan malnutrisi kalori protein sedang, bila lebih dari $30 \%$ berarti sudah terjadi malnutrisi berat. Pengukuran antropometrik (tebal kulit trisep) akurat walaupun pada pasien dengan kondisi kelebihan cairan.

Pasien dengan berat badan $<85 \%$ dari BB ideal atau dengan $\mathrm{BMI}<18,5 \mathrm{~kg} / \mathrm{m}^{2}$ termasuk kategori malnutrisi sedang, sedangkan malnutrisi berat bila $\mathrm{BB}<$ $75 \%$ BB ideal atau BMI $<16 \mathrm{~kg} / \mathrm{m}^{2}$. Subjective Global Aseesement (SGA) adalah suatu metoda untuk mengevaluasi status nutrisi dengan menggunakan parameter anamnesis, pemeriksaan fisik, dan gejala klinis. SGA dapat menentukan apakah ; a. sebab kekurangan nutrisi itu karena kurangnya asupan, maldigesti, atau malabsorpsi, b. pengaruh yang terjadi dari malnutrisi terhadap fungsi organ dan komposisi tubuh, c. apakah proses penyakit yang terjadi mempengaruhi kebutuhan nutisi atau tidak. ${ }^{2}$

Pada kondisi kelaparan (dengan asupan cairan yang cukup) dan tanpa disertai adanya stres metabolik, manusia dapat bertahan hidup sekitar 6-10 minggu. Dalam hal kadar nitrogen total dalam tubuh, apabila terdapat kehilangan sebanyak 350-500 gr maka akan berpotensi menimbulkan kematian, Dari segi BMI, apabila BMI $<13 \mathrm{~kg} / \mathrm{m}^{2}$ pada laki-laki dan BMI $<11 \mathrm{~kg} / \mathrm{m}^{2}$ pada wanita, maka pada kondisi tersebut tubuh tidak akan bisa bertahan hidup. ${ }^{3}$

\section{Respons Tubuh terhadap Sakit Kritis}

Pada pasien kritis, tubuh mengalami berbagai perubahan metabolisme termasuk perubahan penggunaan sumber energi tubuh. Hal ini terjadi karena asupan yang terganggu dan pada keadaan tersebut terjadi suatu hipermetabolisme dan hiperkatabolisme sehingga kebutuhan energi tubuh meningkat. Tubuh memiliki cadangan terutama karbohidrat dan lemak yang sewaktu-waktu dapat dilepaskan. Beberapa organ ada yang membutuhkan glukosa secara mutlak, dan ada juga yang membutuhkan gabungan glukosa dengan lemak. Glukosa dapat dibentuk dari beberapa asam amino melalui glukoneogenesis. Selama kelaparan, terjadi oksidasi lemak sebagai pengganti utama sumber energi dan kehilangan nitrogen akan dikurangi dengan mobilisasi lemak. Ketika cadangan lemak sudah berkurang, dapat berlanjut menjadi kehilangan masa otot yang berat.

Perubahan dalam metabolisme berbagai substrat menyebabkan perubahan komposisi tubuh dan akhirnya menyebabkan kekurangan dari beberapa nutrien. Defisiensi nutrisimengakibatkan turunnya sistem kekebalan tubuh, proses penyembuhan luka yang buruk, multi organ failure, memperpanjang lama perawatan di rumah sakit serta meningkatnya mortalitas. Karena itu, terapi nutrisi penting diberikan dan menjadi bagian dari terapi klinis pada pasien sakit kritis. Perubahan metabolisme tubuh yang terjadi pada pasien sakit kritis:

\section{Hipermetabolisme}

Pada pasien sakit kritis terjadi respons sistemik akibat ketidak seimbangan antara deliveri oksigen dengan persediaan oksigen pada jaringan yang mengalami kerusakan. Sepsis menyebabkan kondisi hipermetabolisme dimana terjadi akselerasi pemecahan protein untuk proses glukoneogenesis dan pembentukan asam amino yang diperlukan untuk meningkatkan sintesa protein. Pada tempat lain seperti otot skelet, hepar, usus dan ginjal kebutuhan oksigen meningkat. Peningkatan metabolisme ini terutama disebabkan oleh adanya inefisiensi penggunaan glukosa pada jaringan yang rusak.

\section{Perubahan metabolisme glukosa}

Glukosa merupakan sumber energi utama pada jaringan yang rusak, untuk memperbaiki jaringan dan proses 


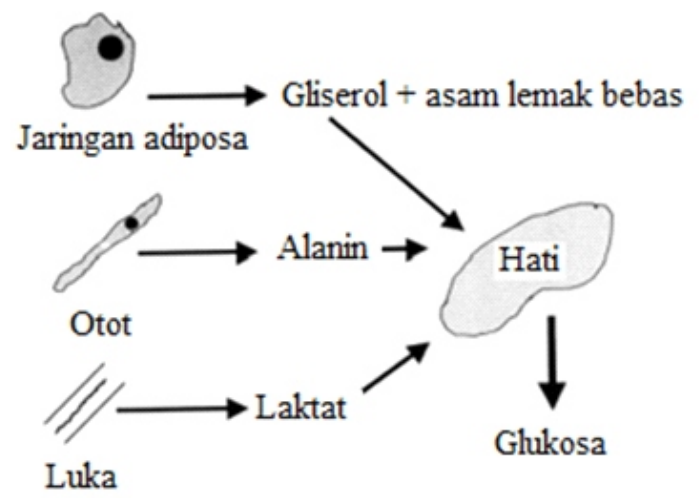

Glukoneogenesis meningkat saat stres. Sumber dari substrat meliputi gliserol dari lipolisis, alanin dari proteolisis, dan laktat dari siklus anaerob

Gambar 1. Glukoneogenesis dalam kondisi strees

Diambil dari Nutritional in the intensive care unit, crit care med 2000

imunitas. Contohnya adalah aktivitas sel PMN sebagai komponen sistem imun dan sel fibroblas yang berperan dalam proses penyembuhan, dalam keadaan anaerob, menjadi sangat bergantung pada glukosa sebagai sumber energi. Glukosa diperoleh dari asupan makanan dan glukoneogenesis. Sumber utama untuk proses glukoneogenesis ini adalah gliserol dari lipolisis, alanin dari proteolisis dan laktat dari glikolisis anaerob.

Peningkatan produksi glukosa melalui glukoneogenesis dan adanya resistensi perifer terhadap insulin, menyebabkan hiperglikemia. Kadar insulin umumnya meningkat akan tetapi tidak cukup untuk mencegah hiperglikemia. Hiperglikemia sendiri sebenarnya merupakan suatu mekanisme kompensasi karena tubuh menyediakan suplai glukosa yang cukup untuk dijadikan sebagai sumber energi pada sel-sel yang hanya menggunakan glukosa sebagai sumber energi (jaringan rusak, leukosit dan sel imunitas lainnya). Resistensi jaringan terhadap insulin disebabkan karena adanya gangguan pada post-reseptor. Oksidasi glukosa menghasilkan ATP, air dan $\mathrm{CO}_{2}$; diubah menjadi glikogen untuk disimpan di hepar dan otot ; atau diubah menjadi lemak (lipogenesis) di hepar dan jaringan adiposa.

Pemberian glukosa atau karbohidrat pada pasien sakit berat hanya sedikit pengaruhnya dalam menurunkan kecepatan glukoneogenesis. Walaupun terjadi penurunan penggunaan glukosa, pemberian glukosa dari luar tetap diperlukan oleh karena beberapa jaringan hanya dapat menggunakan sumber energi berupa glukosa dan pemberian glukosa merangsang sekresi insulin sebagai hormon anabolik yang merangsang sintesa protein dan mencegah lipolisis.

Keadaan hiperglikemia membatasi jumlah glukosa atau karbohidrat yang dapat diberikan. 'TPNinduced hyperglycaemia' tergantung dari kecepatan pemberian glukosa dan derajat penyakit/kerusakan. Pasien tua lebih mudah mengalami hiperglikemia.

Pemberian glukosa yang berlebihan $(>4 \mathrm{mg} / \mathrm{kg}$ per min), terutama pada saat stres akut akan menyebabkan respons thermogenesis, peningkatan konsentrasi gula darah dan peningkatan produksi $\mathrm{CO}_{2}$.

Penggunaan beberapa karbohidrat non glukosa telah diteliti akan tetapi belum ada hasil yang memuaskan. Pemberian sorbitol, fruktosa dan xylitol tidak memuaskan. Gliserol memberikan hasil yang baik, akan tetapi jumlah yang dapat diberikan sangat terbatas.

\section{Perubahan metabolisme protein}

Pada pasien sakit kritis, salah satu ciri dari respons metabolik pada pasien kritis adalah katabolisme (negative nitrogen balance). Pada keadaan ini terjadi proses proteolisis dari otot skelet menjadi alanin yang digunakan sebagai substrat untuk glukoneogenesis di hepar. Karena itu terjadi peningkatan urea nitrogen dalam urin yang terutama dihasilkan oleh pemecahan protein otot. Jumlah ekskresi nitrogen ini berbanding lurus dengan derajat kerusakan jaringan.

Selain akibat pengaruh stres hormon, peningkatan pemecahan protein juga disebabkan oleh TNF-a, IL-1, IL6 dan interferon-ү. Glutamin, alanin, dan asam amino lainnya dimobilisasi dari otot skelet ke sel hepar dan mukosa usus. Beberapa komponen yang berperan dalam metabolisme protein yakni:

a. Glukokortikoid merupakan salah satu mediator respons stres dan mediator utama dalam katabolisme protein. Glukokortikoid mempercepat pelepasan asam amino dari protein otot ke hepar, tempat asam amino ini diubah menjadi sumber glukosa (proses glukoneogenesis) serta pembentukan protein untuk pertahanan tubuh. 
b. Alanin yang dihasilkan dari pemecahan protein merupakan prekursor glukosa utama untuk memproduksi ATP pada keadaan hipermetabolisme.

c. Glutamin, merupakan salah satu asam amino yang berlimpah dalam sirkulasi juga memegang peranan penting dalam metabolisme sakit kritis, karena menjadi sumber energi pembelahan sel dan transport nitrogen antar sel. Glutamin juga berperan dalam proses pembentukan ammonia oleh ginjal untuk menetralisir kelebihan asam akibat peningkatan degradasi protein.

Saat stres, peningkatan pembentukan urea (ureagenesis) menyebabkan peningkatan kehilangan nitrogen. Kadar Glutamin dan BCAA (Branched Chain Amino Acids Leusin, Isoleucin, Valine) menurun. Sementara itu, terjadi peningkatan sintesa acute phase proteins seperti fibrinogen, komplemen, imunoglobulin and C-reactive protein. Peningkatan protein ini bertujuan untuk meningkatkan kemampuan tubuh untuk melawan infeksi. Pada saat yang sama terjadi penurunan sintesa dari 'protein binding' seperti albumin, prealbumin, dan transferrin.

Pemberian tambahan protein pada masa katabolik direkomendasikan sebesar 1-1,5 g/kgBB/hari. Pemberian tambahan protein yang lebih besar akan meningkatkan produksi Blood Urea Nitrogen(BUN). Pada keadaan dimana protein banyak dikeluarkan dari tubuh (luka bakar luas, drain abses), asupan protein harus lebih ditingkatkan. Pemberian Glukosa / karbohidrat yang cukup harus selalu ditambahkan pada nutrisi untuk merangsang sekresi insulin endogen yang berperan dalam menghambat proteolisis. Insulin dosis tinggi juga mempunyai efek anabolik sehingga dapat meningkatkan sintesa protein.

Tanpa intervensi terapi, proses penyembuhan penyakit bergantung dari kemampuan tubuh untuk memecah protein otot menjadi glukosa melalui glukoneogenesis. Proses ini hanya mengandalkan protein, karena sumber glukosa lainnya (lemak dan glikogen) kurang efektif digunakan untuk penyembuhan jaringan. Lemak tidak dapat dimetabolisme tanpa adanya oksigen, sedangkan cadangan glikogen terlalu sedikit untuk memenuhi kebutuhan glukosa yang diperlukan dalam proses penyembuhan jaringan.

\section{Perubahan metabolisme lemak}

Lipolisis terjadi akibat peningkatan stimulasi pada $\beta 2$ adrenergik Peningkatan konsentrasi glukagon, TNF-a, IL-1, dan interferon-ү juga berperan dalam merangsang lipolisis. Peningkatan lipolisis ini menyebabkan peningkatan dari asam lemak bebas dalam darah. Peningkatan aktivitas Siklus Asam Lemak - Trigliserida ini merupakan salah satu penyebab dari hipermetabolisme saat stres.

TNF, IL-1, IL-6 menurunkan aktivitas enzim lipoprotein lipase, sehingga menyebabkan trigliseridemia. Ketosis umumnya tidak terjadi. Hal ini menunjukkan bahwa lemak bukanlah sumber energi utama saat stres.

Pada dengan kondisi sakit kritis, mengalami stres katabolik dan respons inflamasi sistemik. Respons metabolisme ini mempengaruhi morfologi dan fungsi saluran gastro Intestinal (GI). Hampir $60 \%$ pasien ICU mengalami disfungsi GI karena gangguan motilitas, gangguan dalam mencerna, dan gangguan penyerapan. Dengan disfungsi GI yang seringkali diikuti dengan asupan kalori yang tidak adekuat, akhirnya menyebabkan kekurangan energi dan penurunan masa tubuh. Status gizi yang buruk ini berhubungan dengan keadaan klinis dan hasil pasien.

Pasien-pasien ICU dengan status gizi kurang, biasanya mengalami disfungsi sistem imun, otot-otot pernapasan melemah hingga menurunkan kapasitas ventilasi, dan menurunkan toleransi GI. Akibatnya pasien dapat mengalami berbagai macam komplikasi diantaranya, ketergantungan ventilator, disfungsi GI dengan refluks gastroesofageal, esofagitis, aspirasi pulmoner, infeksi yang dapat menyebabkan sepsis, kegagalan multi organ, hingga menyebabkan kematian. Untuk pasien-pasien ini, dukungan nutrisi sudah lama digunakan sebagai tambahan perawatan, namun seringkali nutrisi yang diberikan tidak adekuat, hanya makronutrien fundamental saja untuk mempertahankan pasien dalam keadaan stres metabolik. ${ }^{4}$

\section{Kebutuhan Nutrisi}

Terdapat 3 bahan bakar yang digunakan pada tubuh manusia, yaitu karbohidrat, potein, dan lemak. Energi yang dihasilkan dari pembakaran bahan bakar tersebut dinyatakan dengan produksi panas dalam satuan kilo kalori (kkal) per gram substrat.

Kebutuhan energi harian tiap individu dapat diperkirakan ataupun diukur. Pada awal abad ke 20, telah dilakukan pengukuran kebutuhan energi harian pada suatu kelompok dewasa sehat (136 laki-laki dan 103 perempuan), dari studi tersebut didapatkan hasil, yaitu suatu rumusan yang bergantung pada jenis kelamin, berat badan, tinggi badan. Rumus tersebut dikenal dengan Harris Bennedict.

Kebutuhan energi harian digambarkan sebagai kebutuhan energi basal atau basal energi expenditure (BEE). Untuk memenuhi efek panas dari asupan makanan, maka BEE dikalikan dengan 1,2 dan dinamakan resting energi expenditure (REE), dimana merupakan suatu kebutuhan energi pada metabolisme basal dalam kondisi istirahat tanpa disertai kondisi puasa. ${ }^{1}$

Faktor yang menentukan total kebutuhan kalori adalah masa sel tubuh. Kebutuhan energi dapat diperkirakan atau diukur secara langsung dengan menggunakan kalorimetri indirek. Dikarenakan 


\begin{tabular}{|lcccc|}
\hline $\begin{array}{l}\text { TABEL } 1 \\
\text { Metabolisme oksidatif dari bahan bakar organik }\end{array}$ & & \\
\hline Sumber & $\mathbf{V O}_{\mathbf{2}}(\mathbf{L} / \mathbf{g})$ & $\mathbf{V C O}_{\mathbf{2}}(\mathbf{L} / \mathbf{g})$ & $\mathbf{R Q}$ & Energi (kkal/g) \\
\hline Lipid & 2,00 & 1,40 & 0,70 & 9,1 \\
Protein & 0,96 & 0,78 & 0,80 & 4,0 \\
Karbohidrat & 0,74 & 0,74 & 1,00 & 3,7 \\
\hline
\end{tabular}

\section{TABEL 2}

\section{Metode kebutuhan energi}

dengan rumus Harris Bennedict

Kebutuhan energy basal (BEE)

Laki-laki (kcal/24jam) :

$66+(13,7 \times B B)+(5 \times T B)(6,7 \times$ umur $)$

Perempuan :

$65+(9,6 \times B B)+(1,8 \times T B)(4,7 \times$ umur $)$

(BB dalam $\mathrm{kg}$, tinggi dalam inches)

Resting Energy Expenditure (REE)

$B E E \times 1,2$

penggunaan estimasi kebutuhan energi dapat memperlihatkan hasil yang adekuat pada kebanyakan pasien, maka pengukuran secara langsung bisasnya hanya dilakukan pada pasien yang sulit diperkirakan kebutuhan energinya atau pada pasien yang tidak respons terhadap terapi nutrisi yang sudah diberikan (perburukan fungsi nafas, penurunan berat badan yang terus menerus atau penurunan level prealbumin), prealbumin merupakan marker yang lebih sensitif dubandingkan dengan albumin).

Prinsip utama dari dukungan makronutrisi adalah untuk menyediakan energi yang cukup untuk menjaga fungsi anabolik dan mencegah kalori yang berlebihan. Kebutuhan kalori yang biasa digunakan adalah $2530 \mathrm{kkal} / \mathrm{kgBB} /$ hari, dan hasil tersebut cukup pada kebanyakan pasien. Bila pasien tidak respons dengan jumlah tersebut atau bila pasien dalam kondisi katabolik berat (luka bakar atau trauma multiple) maka pada kondisi tersebut bisa diberikan 30-40 kkal/kgBB/hari. ${ }^{2}$

Kebutuhan energi harian harus dipenuhi oleh kalori yang berasal dari karbohidrat dan lemak, dan asupan protein digunakan untuk kebutuhan enzim esensial dan struktur tubuh. Proporsi dari kalori harian yang disajikan dari lemak dan karbohidrat masih menjadi perdebatan, namun belum ada bukti yang bisa menunjukan substrat mana yang lebih superior sebagai sumber kalori. ${ }^{1}$

\section{Karbohidrat}

Karbohidrat mensuplai sekitar 70\% kalori nonprotein pada rata-rata asupan makanan, tubuh manusia memiliki cadangan karbohidrat yang terbatas, sehingga asupan karbohidrat harian sangatlah penting untuk memastikan sistes saraf pusat berfungsi dengan baik, hal ini sangat tergantung dari glukosa sebagai bahan bakarnya. Sebaliknya, asupan yang berlebihan akan meneyebabkan kerusakan karena :

1. Karbohidrat akan menstimulasi pelepasan insulin, dan menghambat mobilisasi asam lemak bebas dari jaringan adipose. Karena jaringan adipose merupakan sumber kalori endogen utama, maka asupan karbohidrat yang berlebihan akan merusak kemampuan tubuh untuk bergantung pada cadangan lemak endogen.

2. Metabolisme oksidatif dari glukosa akan menghasilkan banyak CO2. Oleh karena itu kabohidrat yang berlebihan dapat menyebabkan produksi $\mathrm{CO} 2$ yang berlebihan, sehingga akan memicu terjadinya hiperkapnia pada pasien dengan gangguan fungsi paru. ${ }^{1}$

Secara umum pasien membutuhkan sekitar 25-30 $\mathrm{kkal} / \mathrm{kgBB} /$ hari untuk memenuhi kebutuhan energi. Sekitar $20 \mathrm{kkal} / \mathrm{kgBB} /$ hari dari BB aktual dapat dipenuhi dari karbohidrat. Kadar karbohidrat diatas 30 kkal/kgBB/hari akan meningkatkan resiko hiperglikemia, hal ini harus dihindari karena berhubungan dengan terjadinya adesi granulosit, fagositosis, dan menyebabkan hasil yang buruk. Hiperglikemia juga merupakan penyebab utama infeksi post operasi. Kadar gula $>220 \mathrm{~g} / \mathrm{dL}$ pada hari ke 1 pot operasi meningkatkan resiko infeksi yang serius. ${ }^{2}$

Fisiologi tubuh untuk batas asupan karbohidrat sesuai dengan laju produksi hepatik endogen untuk glukosa, yaitu sebesar $2 \mathrm{mg} / \mathrm{kg} /$ menit atau sekitar 200 gr/24 jam, pada BB $70 \mathrm{~kg}$, hal ini merupakan jumlah glukosa yang dibutuhkan tubuh untuk memenuhi kebutuhan organ yang tegantung pada glukosa (otak, ginjal, sel darah merah). ${ }^{3}$

\section{Lemak}

Asupan lemak menghasilkan energi yang paling tinggi bila dibandingkan dengan karbohidrat atau protein. Cadangan lemak di jaringan adipose merupakan sumber bahan bakar utama pada pasien dewasa sehat. Kebanyakan ahli nutrisi menggunakan lemak sebagai regimen untuk menyediakan sekitar 30\% dari energi harian yang dibutuhkan. ${ }^{1}$ 
Pemberian lemak biasanya tidak lebih dari 20\% dari total kebutuhan kalori perhari. Poly Unsaturated Fatty Acids (PUFA) omega 6 harus diberikan dalam dosis yang cukup untuk mencegah defisiensi asam lemak (setidaknya 7\% dari total pemberian kalori). Medium Chain trigiserid (MCTs) dapat diberikan bersama dengan Long chain trigliserid (LCTs). MCTs lebih bersifat larut air dan lebih sedikit membutuhkan asam empedu untuk absorpsinya. Sehingga akan lebih mudah diabsorpsi pada pasien insufisiensi pankreas. ${ }^{2}$

\section{Protein}

Tujuan asupan protein adalah untuk proses katabolisme. Asupan protein dapat diperkirakan dengan menggunakan prediksi untuk pasien sehat maupun pasien dengan kondisi hiperkatabolik (normal 0,8-1 $\mathrm{g} / \mathrm{KgBB} /$ hari, sedangkan untuk hiperkatabolik 1,2-1,6 $\mathrm{g} / \mathrm{KgBB} /$ hari). Untuk menentukan kebutuhan asupan protein yang lebih akurat dibutuhkan beberapa perhitungan dari katabolisme protein, yaitu dihitung dari ekskresi nitrogen pada urin.

Dua pertiga nitrogen dihasilkan dari pemecahan protein yang kemudian diekskresikan melalui urin. Total keseimbangan nitrogen dapat dirumuskan sebagai berikut:

$$
N \text { balance }(g)=(\text { protein asupan }(g) / 6,25) \quad(U U N+4)
$$

UUN adalah ekskresi urea melalui urin dalam satuan gram perhari. Nilai normal dari keseimbangan nitrogen adalah positif 4-6 gram. ${ }^{1}$ Kebutuhan protein berkisar antara 1,2-1,5 g/ kgBB/hari untuk berat badan aktual, sambil di monitor kadar nitrogen untuk menyesuaikan pemberian protein, asupan dikurangi bila kadar urea nitrogen darah meningkat hingga 100 mg/dL atau bila kadar ammonia meningkat, karena bisa menimbulkan ensefalopati uremikum. ${ }^{2}$

Kebutuhan jumlah dan jenis protein pada pasien sakit kritis tergantung dari kondisi klinisnya. Namun demikian, ada batas maksimal dari jumlah protein yang dapat diberikan berdasarkan protein yang digunakan saat adanya stres metabolik. Pemberian protein lebih dari $1,75 \mathrm{~g} / \mathrm{kg} /$ hari melebihi kapasitas tubuh untuk menggunakan protein tersebut.

Asupan protein optimal pada pasien sakit kritis adalah $2 \mathrm{kali}$ dari kebutuhan harian $(0,8 \mathrm{~g} / \mathrm{kg} / \mathrm{hari})$, yaitu sekitar $1,5 \mathrm{~g} / \mathrm{kg} /$ hari. Pada pasien dengan gangguan fungsi ginjal, pemberian protein setidaknya $1 \mathrm{~g} / \mathrm{kg} /$ hari, sedangkan pemberian lebih dari itu bisa diberikan bila pasien menjalani dialisis. Jenis protein yang diberikan bervariasi tegantung dari kondisi dan rute pemberian. Untuk dukungan parenteral, standar protein yang diberikan adalah dalam bentuk monomerik sebagai asam amino kristalin dan levoratori isomer yan meliputi asam amino esensial dan non esensial. Sediaan yang tersedia mulai dari $3-15 \%$.
Untuk nutrisi enteral, asupan protein tersedia dalam bentuk oligomer sebagai protein hidrolisa yang mengandung peptida yang bervariasi atau dalam bentuk polimer, contohnya kasein hidrolisa. ${ }^{3}$

\section{Vitamin, Volume, dan Elektrolit}

Terdapat 12 vitamin yang dianjurkan dan merupakan vitamin esensial untuk asupan harian. dua vitamin penting yang berperan sebagai antioksidan endogen yaitu vitamin $\mathrm{C}$ dan $\mathrm{E}$. Vit $\mathrm{E}$ adalah antioksidan larut lemak utama dalam tubuh, sedangkan vit $C$ adalah antioksidan larut air dan merupakan antioksidan utama didalam cairan ekstraseluler. ${ }^{1}$

Memelihara keseimbangan cairan merupakan tujuan yang penting dalam perawatan pasien kritis. Banyak pasien di ICU mengalami kelebihan cairan akibat pemberian cairan parenteral yang berlebihan maupun karena adanya retensi cairan. Pada dewasa normal total body weight (TBW) berkisar 50-60\% dari berat badan. Peningkatan berat badan lebih dari 10\% dalam 24-48 jam akan menunjukan proporsi peningkatan TBW dan akan mempengaruhi kondisi klinis. Misalnya kebutuhan ventilator akan meningkat, terjadi ganggun fungsi jantung, gangguan keseimbangan elektrolit. ${ }^{3}$

\section{Kalsium}

Sekitar $98 \%$ total kalsium terdapat di tulang, konsentrasinya di dalam plasma hanya sebagian kecil. Kalsium diregulasi oleh hormon paratiroid. Apabila absoprsinya di saluran pencernaan berkurang atau terjadi penurunan dari asupannya maka glandula paratiroid akan mensekresi hormon paratiroid untuk memobilisasi kalsium dari tulang menuju ke plasma. Parenteral Recommendation Dietary Allowance (pRDA) pada dewasa adalah $25 \%$ dari Oral Recommendation Dietary Allowance (RDA) yakni 200mg (10meq atau $5 \mathrm{mmol})$ perhari.

\section{Magnesium}

Magnesium merupakan kation intrasel yang memegang peranan penting dalam metabolism kalsium. Dalam kasus tertentu koreksi dari serum magnesium sudah cukup untuk menormalkan hipokalemia. pRDA sekitar $33 \%$ dari oral RDA atau $120 \mathrm{mg}$ (10meq atau $5 \mathrm{mmol}$ ) perhari.

\section{Fosfor}

Merupakan elemen esensial yang berfungsi dalam mempertahankan proses metabolisme, seperti kalsium dan magnesium. Fosfor paling banyak ditemukan di intraseluler, karena absorpsi fosfor di saluran pencernaan sangat efisien, $\mathrm{pRDA}$ untuk fosfat sama dengan oral RDA yaitu $1000 \mathrm{mg}$ (30mmol) perhari. 


\section{Sodium}

Banyak yang menganjurkan jumlah harian sodium antara 60-100meq pehari, namun kondisi klinis tertentu mengharuskan pemberian dibawah nilai tersebut. Misalnya pada pasien gagal jantung, gagal ginjal stadium terminal, dan pada kondisi dimana tubuh harus mengurangi kebutuhan cairan.

\section{Potasium}

Sering diberikan dengan jumlah 40-80 meq perhari, kecuali pada kondisi tertentu dimana bisa direstriksi maupun diberikan dalam jumlah yang besar hingga 400meq perhari. Serum potassium harus dimonitor secara ketat karena batas keamanannya yang sempit dan bisa menimbulkan komplikasi kardiovaskuler yang mengancam nyawa.

\section{Klorida}

Garam klorida diberikan secara luas untuk menopang nutrisi, paling sering bersamaan dengan sodium dan potassium. Sekresi di gaster merupakan penyebab utama dari kehilangan klorida yang menyebabkan alkalosis hipokloremik. Klorida eksogen dan gagal ginjal merupakan penyebab utama dari asidosis hiperkloremik. ${ }^{3}$

\section{Rute Pemberian dan Komplikasi}

\section{Enteral}

Pada studi klinis pemberian makanan melalui enteral dapat mengurangi infeksi dan menjaga integritas usus, barier, dan fungsi imun. Rute ini lebih disukai untuk pemberian nutrisi karena lebih fisiologis, aman, dan lebih murah dibandingkan dengan rute parenteral.

Rekomendasi saat ini menyarankan pemberian inisiasi nutrisi enteral lebih dini pada pasien dengan hemodinamik yang stabil. Kontra indikasi rute enteral adalah bila usus tidak berfungsi dengan baik. pemberian makan intragastrik membutuhkan motilitas yang adekuat, sehingga residu gaster harus dipantau tiap jam. Bila volume lebih dari 200cc, maka harus diganti melalui rute parenteral untuk meminimalisasi refluks dan aspirasi.

Inisiasi pemberian enteral tidak harus menunggu adanya bising usus, flatus, maupun defekasi. Adanya distensi abdomen atau diare yang lebih dari $1000 \mathrm{cc} / \mathrm{hari}$ membutuhkan evaluasi medis. Bila terjadi distensi abdomen makan enteral feeding harus distop. Bila tidak ada infeksi pada diare maka dapat diberikan obat anti diare dan pemberian nutrisi diteruskan.

Secara umum komplikasi yang sering terjadi berkaitan dengan penempatan selang makanan atau malfungsi dari selang. Posisi dari nasogastrik atau nasoenterik selang harus dikonfirmasi secara endoskop atau radiografi sebelum digunakan. Selang harus sering dibilas untuk mencegah terjadinya sumbatan dari sisa obat maupun makanan.

Penempatan selang melalui gastroesofagal junction atau pylorus dapat memicu terjadinya gangguan spinchter, refluks, dan aspirasi. Pada pasien yang memiliki resiko tejadinya aspirasi atau dengan riwayat aspirasi sebelumnya disarankan dengan penggunaan perkutaneus. Disarankan untuk mengelevasi kepala $30^{\circ}$ dan melakukan pemeriksaan residu gaster untuk mencegah peningkatan volume isi gaster yang dapat menyebabkan refluks.

Stres gaster, adalah stres related erosive syndrome (SRES), yaitu cedera mukosa gastrointestinal yang diakibatkan karena penyakit sistemik yang berat. $^{2}$

\section{Parenteral}

Pemberian nutrisi parenteral direkomendasikan apabila terdapat gangguan dari traktus digestif atau terjadi insufisiensi dari enteral feeding. Nutisi parenteral berhubungan dengan peningkatan komplikasi infeksi dan tingginya biaya. Dibutuhkan perhatian khusus terhadap tindakan aseptik untuk bisa menurunkan angka kejadian komplikasi. ${ }^{2}$

\section{Komplikasi}

Kepatuhan terhadap panduan kebutuhan energi yang sudah dijelaskan sebelumnya akan membantu kita untuk bisa menghindari terjadinya overfeeding, karena overfeeding dapat memicu berbagai masalah seperti kolestasis, hiperglikemia, peningkatan infeksi, dan perburukan dari kondisi gagal nafas hiperkapnik. Respiratory Quotient (R/Q) lebih dari 1 mengindikasikan tejadinya overfeeding, $\mathrm{R} / \mathrm{Q}$ adalah perbandingan dari produksi CO2 dalam $\mathrm{ml}$ per konsumsi $\mathrm{O} 2$ dalam $\mathrm{ml}$, Peningkatan produksi CO2 akan menyebabkan peningkatan $\mathrm{R} / \mathrm{Q}$ dari nilai normalnya yaitu 0,8 .

Penilaian keseimbangan nitrogen (perbedaan antara produksi dan eliminasinya melalui urin dan tinja) setiap 5-7 hari dapat membantu untuk menentukan kebutuhan protein. ${ }^{2}$

\section{Panduan Surviving Sepsis Campaign}

1. Disarankan pemberian makan secara oral atau enteral (bila perlu) sepanjang dapat ditoleransi, daripada dipuasakan atau diberikan glukosa intravena 48 jam pertama setelah diagnosis sepsis berat / syok septik (grade 2C).

Alasan

Pemberian nutrisi enteral dini secara teori memiliki keuntungan, diantaranya menjaga integritas mukosa usus, pencegahan translokasi bakteri, dan disfungsi organ. Namun perlu juga dipikirkan resiko iskemia, terutama pada pasien dengan hemodinamik yang tidak stabil.

Penelitian belum ada yang menunjukkan adanya efek yang konsisten pada mortalitas dan tidak ditemukan bukti bahaya pemberian nutrisi enteral dini. Bukti 
manfaat pemberian nutrisi dini antara lain berkurangnya kejadian komplikasi infeksi, mengurangi lama ventilasi mekanik, mengurangi lama rawat di ICU dan lama rawat inap di rumah sakit. Dengan tidak adanya bahaya dan adanya manfaat yang telah diketahui, maka pemberian nutrisi enteral dini dibenarkan.

2. Disarankan untuk menghindari pemberian kalori penuh pada minggu pertama, dan lebih baik diawali kalori dosis rendah (misalnya, hingga $500 \mathrm{kkal}$ per hari), ditingkatkan hanya sepanjang yang dapat ditoleransi (grade 2B).

Alasan

Pemberian nutrisi enteral penuh tidak disarankan. Karena hasil beberapa penelitian menunjukkan adanya peningkatan komplikasi infeksi, peningkatan diare dan residual lambung, peningkatan kejadian komplikasi infeksi, dan angka kematian lebih tinggi.

3. Disarankan penggunaan glukosa intravena dan nutrisi enteral daripada total parenteral nutrisi (TPN) saja, atau nutrisi parenteral ditambah dengan makanan enteral, dalam 7 hari pertama setelah Alasan diagnosis sepsis berat / syok septik (grade 2B).

Tidak ada bukti yang menunjukkan adanya manfaat atau suatu yang membahayakan dari pemberian nutrisi parenteral saja pada 48 jam pertama pasien sepsis. Tidak ada manfaat penurunan mortalitas dengan pemberian nutrisi parenteral. Beberapa penelitian menunjukkan bahwa nutrisi parenteral memiliki komplikasi infeksi lebih tinggi dibandingkan pemberian glukosa intravena dan nutrisi enteral. Ditemukan juga bahwa pemberian nutrisi parenteral memperpanjang waktu rawat di rumah sakit dan ICU, insidensi infeksi lebih tinggi, dan lebih lama dalam penggunaan alat bantu fungsi organ. Dengan demikian, tidak ada studi yang menunjukkan keunggulan TPN dibandingkan nutrisi enteral. Bahkan diusulkan bahwa nutrisi enteral lebih unggul dibandingkan TPN karena kemungkinan resiko infeksi dan membutuhkan perawatan intensif dan alat bantu yang lebih lama.

4. Disarankan penggunaan nutrisi tanpa suplementasi imunomodulasi spesifik pada pasien dengan sepsis berat (grade 2C).

Alasan

Menurut teori, suplemen nutrisi imunomodulasi spesifik seperti pemberian Arginine, Glutamine, Omega 3, dan Omega 6 dikatakan dapat bermanfaat.

Arginin berkurang pada sepsis, yang dapat menyebabkan penurunan sintesis nitric oxide, penurunan mikro sirkulasi, meningkatkan superoksida dan peroxynitrite yang merupakan radikal berbahaya. Namun, suplementasi arginin diketahui dapat menyebabkan vasodilatasi yang tidak diinginkan dan hipotensi. Penelitian-penelitian menunjukkan tidak ada manfaat atau kemungkinan berbahaya pada pasien septik. Temuan manfaat seperti mengurangi komplikasi infeksi dan mengurangi lama tinggal di RS diragukan relevansinya jika terdapat potensi bahaya pemberian arginin.

Glutamin juga berkurang selama keadaan kritis. Suplementasi glutamin diketahui dapat memperbaiki atrofi dan permeabilitas mukosa usus, dan akhirnya menghambat translokasi bakteri. Manfaat potensial lainnya adalah meningkatkan fungsi sel imun, penurunan produksi sitokin pro-inflamasi, meningkatkan glutathione, dan kapasitas antioksidan. Namun, signifikansi klinis temuan ini belum dapat ditegakkan dengan jelas. Penelitian meta-analisis menunjukkan adanya penurunan angka kematian, namun ada empat meta-analisis lainnya yang mengatakan tidak terdapat penurunan angka kematian. Studi terbaru yang cukup besar, tidak bisa menunjukkan adanya pengurangan komplikasi infeksi dan disfungsi organ. Tidak ada bukti manfaat yang jelas dari suplementasi glutamin, meskipun tidak ada tanda-tanda bahaya.

Pemberian omega-3 diharapkan dapat mengurangi dampak pro-inflamasi pada respons imun. Omega-3 dalam bentuk eicosapentaenoic acid (EPA) dan gamma-linolenic acid (GLA) merupakan prekursor eicosanoid yang dapat menghasilkan prostaglandin, leukotrien, dan tromboksan yang akan menekan dampak pro-inflamasi. Penelitian yang dilakukan menemukan ada penurunan yang signifikan pada angka kematian, peningkatan jumlah hari yang bebas dari ventilator, dan mengurangi risiko disfungsi organ baru. Bagaimanapun, hanya satu penelitian yang dilakukan pada pasien sepsis, dan penelitian ini menggunakan diet tinggi omega-6 pada kelompok kontrol, yang bukanlah standar umum pada perawatan sakit kritis. Penelitian dengan minyak ikan enteral atau parenteral tidak dapat menunjukkan bukti temuan tersebut pada penyakit kritis yang umum.

Dengan demikian, tidak ada temuan besar yang menunjukkan manfaat jelas dari penggunaan suplemen imunomodulasi pada sepsis. ${ }^{5}$

\section{SIMPULAN}

Pemberian nutrisi enteral dan parenteral diberikan bukan untuk memenuhi target kebutuhan, tetapi untuk mentoleransi keadaan yang direncanakan dari tindakan atau pengelolaan medis lain. Rekomendasi pemberian nutrisi enteral dini direkomendasikan sangat bermanfaat pada pasien sakit kritis, walaupun pemberian nutrisi enteral sendiri dapat memungkinkan terjadinya kekurangan nutrisi. Cara pemberian dan kebutuhan harus disesuaikan dengan kebutuhan individu pasien, sehingga jika pemberian enteral kurang, sebaiknya dikombinasikan dengan pemberian nutrisi melalui 
parenteral.

Pemberian nutrisi pada pasien-pasien yang dirawat di rumah sakit seringkali tidak mendapat proporsi yang seharusnya dibandingkan dengan terapi medikamentosa lainnya.

Nutrisi menjadi sangat penting pada pasien sakit berat dimana ancaman terhadap defisiensi nutrisi kemungkinan besar terjadi. Pada keadaan inilah nutrisi menjadi bagian dari suatu terapi medikal klinis.

Dengan berkembangnya pengetahuan tentang nutrisi memungkinkan kita untuk memahami proses metabolik yang terjadi selama sakit dan dapat mengurangi ataupun mencegah morbiditas dan mortalitas akibat berlangsungnya proses metabolik yang terjadi selama sakit dengan berbagai komplikasinya.

Tujuan pemberian nutrisi pada pasien sakit berat adalah untuk mengurangi kehilangan depot nutrisi tubuh, mengurangi kehilangan jaringan akibat proses katabolisme dan memelihara serta memperbaiki fungsi organ seperti ginjal, hepar, otot dan fungsi imunitas. Tujuan spesifik dari pemberian nutrisi ini adalah untuk memperbaiki penyembuhan luka, mengurangi infeksi, mempertahankan mukosa usus (mengurangi translokasi bakteri) dan mengurangi morbiditas serta mortalitas. Semua ini berpengaruh dalam menurunkan lama dan biaya perawatan di rumah sakit.

\section{DAFTAR PUSTAKA}

1. Marino, The ICU book $3^{\text {rd }}$ ed, Metabolic Substrat Requirements, Chapter 45. New York, 2006.

2. Dominic J, Irwin and Rippe's Intensive Care Medicine $7^{\text {th }}$ ed, Nutritional Therapy in the Critically Ill Patient, Chapter 190. Lippincott William \& Wilkins, 2011.

3. David F, Bruce R, Irwin and Rippe's Intensive Care Medicine $7^{\text {th }}$ ed, Parenteral and Enteral Nutrition in the Intensive Care Unit, Chapter 191. Lippincott William \& Wilkins, 2011.

4. Weissman, Nutrition in the Intensive Care Unit, Crit Care Med 2000,3:R67-R75.

5. Dellinger, Levy, Rhodes, et al : Surviving Sepsis Campaign : International Guideline for Management of Severe Sepsis and Septic shock: 2012. Crit Care Med : 2013:41:580 637. 